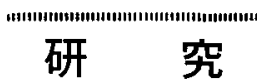

\title{
High Oxygen Pressure Synthesis and Magnetic and Electrical Properties of $\mathrm{Li}_{x} \mathrm{M}_{1-x} \mathrm{Co}_{2} \mathrm{O}_{4}(\mathrm{M}=\mathrm{Co}, \mathrm{Zn}){ }^{*}$
}

\author{
Masao Ohashi**, Masahiko Shimada*** and Mitsue Koizumi
}

\begin{abstract}
The cubic spinel type oxides, $\mathrm{Li}_{x} \mathrm{M}_{1-x} \mathrm{Co}_{2} \mathrm{O}_{4}(\mathrm{M}=\mathrm{Co}, \mathrm{Zn})$, were synthesized under high oxygen pressures. From the result of crystallographic and magnetic properties, the cation distributions of the present systems were determined to be $\left(\mathrm{Li}_{x}^{+} \mathrm{Co}_{1-x}^{2+}\right)\left[\mathrm{Co}_{2-x}^{\mathbb{Q}+} \mathrm{Co}_{x}^{4+}\right] \mathrm{O}_{4}(0 \leqq x \leqq 0.4)$ and $\left(\mathrm{Li}_{0.22}^{+} \mathrm{Zn}_{0,66}^{2+} \mathrm{Co}_{0.12}^{2+}\right)$ $\left[\mathrm{Co}_{1.78}^{\mathbb{I I}+} \mathrm{Co}_{0.22}^{4+}\right] \mathrm{O}_{4}$. Electrical resistivity data indicate that the electron transport in these systems occurs owing to a hopping mechanism between $\mathrm{Co}^{+1}$ and $\mathrm{Co}^{4+}$ ions located at octahedral site.
\end{abstract}

(Received August 10, 1983)

\section{Introduction}

The crystal structure and magnetic properties of spinel type oxides containing first row transition metal ions have been long studied by many investigators. Especially, the studies on the cation distribution and valency state of cations of spinel type oxides have conducted in detail, because magnetic and electrical properties are strongly affected by these factors. Among spinel type oxides, $\mathrm{Fe}_{3} \mathrm{O}_{4}$ is well known as a mixed valency compound and its magnetic and electrical properties are quite interesting owing to the mixed valency state of Fe ions. In the system of 1-3-4 spinels such as $\mathrm{LiTi}_{2} \mathrm{O}_{4}{ }^{1)}, \mathrm{LiV}_{2} \mathrm{O}_{4}{ }^{2}$, and $\mathrm{LiMn}_{2} \mathrm{O}_{4}{ }^{3}$ ), the trivalent and tetravalent states of $\mathrm{Ti}, \mathrm{V}$ and $\mathrm{Mn}$ ions exist at the octahedral site. To explain quite high electrical conductivity of these compounds, "hopping mechanism" has been proposed. The perovskite type oxides containing the tetravalent state of first row transition metal ions of iron group such as $\mathrm{CaFeO}_{3}{ }^{4}$ ), $\mathrm{SrCoO}_{3}{ }^{5)}$ have been synthesized under high temperature and high oxygen gas pressure conditions. Among the oxides containing the tetravalent state of the first row transition metal ions, oxides with rutile and perovskite type structures are well known, and their physical properties are also systematically examined. But, in the spinel type oxides, there have been little report on synthesis and physical properties of spinel type oxides containing tetravalent state of the iron group. In 1981, Appandairajan et al. ${ }^{6)}$ suggested that $\mathrm{Co}^{4+}$ ions would exist in the spinel type cobaltite system $\mathrm{Li}_{x} \mathrm{M}_{1-x} \mathrm{Co}_{2} \mathrm{O}_{4}(\mathrm{M}=\mathrm{Co}, \mathrm{Zn})$ synthesized in a stream of oxygen gas. But the magnetic properties were not examined and also the electron con-

* 昭和 58 年 5 月本協会春季大会䎲て発表，昭和 58 年 8 月 10 日受理，

** Present Address: Department of Applied Chemistry, Faculty of Engineering, Hiroshima University, Hiroshima 724, Japan.

*** To whom correspondence should be addressed; Present Address: Department of Applied Chemistry, Faculty of Engineering, Tohoku University, Sendai, Miyagi 980, Japan. 
figuration of $\mathrm{Co}^{4+}$ ions was not discussed in detail. In the present investigation, we have synthesized the spinel type oxides $\mathrm{Li}_{x} \mathrm{M}_{1-x} \mathrm{Co}_{2} \mathrm{O}_{4}(\mathrm{M}=\mathrm{Co}, \mathrm{Zn})$ under high oxygen gas pressure conditions using cubic type high pressure apparatus. Magnetic and electrical properties were measured. In this paper, we report the preparation method under high oxygen gas pressure and cation distributions and behavior of $3 \mathrm{~d}$ electrons in the lithium-substituted cobaltite spinel containing $\mathrm{Co}^{4+}$ ions.

\section{Experimental}

All $\mathrm{Li}_{x} \mathrm{M}_{1-x} \mathrm{Co}_{2} \mathrm{O}_{4}(\mathrm{M}=\mathrm{Co}, \mathrm{Zn}$ ) samples were prepared by the following preparation techniques. The starting materials were $\mathrm{LiNO}_{3}, \mathrm{Zn}\left(\mathrm{NO}_{3}\right)_{2} \cdot 6 \mathrm{H}_{2} \mathrm{O}$ and $\mathrm{Co}\left(\mathrm{NO}_{3}\right)_{2} \cdot 6 \mathrm{H}_{2} \mathrm{O}$ powders. The nitrate solutions (2M) were prepared and mixed in the desired ratios. After mixed solutions were evaporated to dryness at $100^{\circ} \mathrm{C}$, they were calcined in air at $600^{\circ} \mathrm{C}$ for $10 \mathrm{hr}$, then ground and fired in air at $600^{\circ} \mathrm{C}$ for $24 \mathrm{hr}$. Black powders obtained in this way were subjected to high temperature and high oxygen gas pressure conditions. The present high pressure cell is illustrated in Fig. 1. The starting sample and dry $\mathrm{KIO}_{4}$, which was used to generate oxygen by decomposition at higher temperature, were charged in a gold tube. To prevent the reaction of $\mathrm{KIO}_{4}$ with the starting sample, a disc of $\mathrm{ZrO}_{2}$ was inserted between them as shown in the right side of Fig. 1. The gold tube shown in the right side of this figure was placed in the high pressure pyrophyllite cell as shown in the left side of Fig. 1 and treated at desired temperature-pressure conditions using cubic type high pressure apparatus. After being maintained at $2.5 \mathrm{GPa}$ and $800^{\circ} \mathrm{C}$ for $30 \mathrm{~min}$, the sample was abruptly cooled to room temperature before the pressure was released.

Phases of the products were identified by $\mathrm{X}$-ray powder diffraction and the chemical compositions of products were determined by an atomic absorption spectro-chemical analysis. The lattice parameters of the products were calculated from high angle reflections using Si as a standard material. Magnetic properties were measured using a magnetic torsion balance in the temperature range of 80 to $280 \mathrm{~K}$. The electrical resistivity was measured by a standard four-probe technique in the temperature range of 200 to $300 \mathrm{~K}$.

\section{Results and Discussion}

\section{III-1 $\mathrm{Li}_{x} \mathrm{Co}_{3-x} \mathrm{O}_{4}$ System}

X-ray powder diffraction patterns of the samples with $x=0,0.2$ and 0.4 for starting chemical compositions were completely indexed as the cubic spinel type structure. Whereas the sample with $x=0.6$ was consisted of two phases; the main spinel phase and trace of $\mathrm{LiCoO}_{2}$ phase. The contents

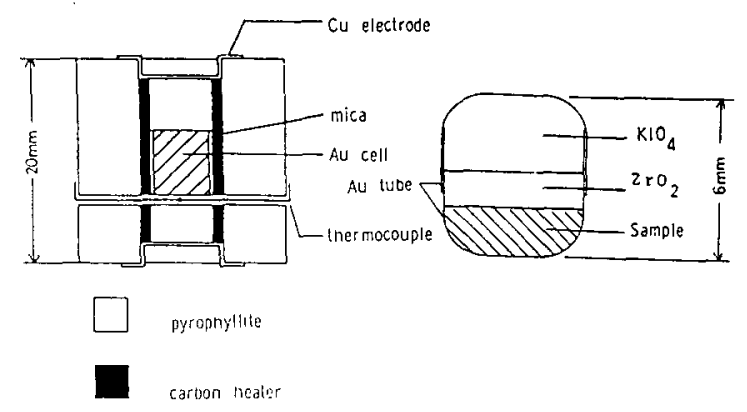

Pyrophyllite cell

Au cell

Fig. 1 High pressure pyrophyllite cell and gold tube sandwiched cell. 


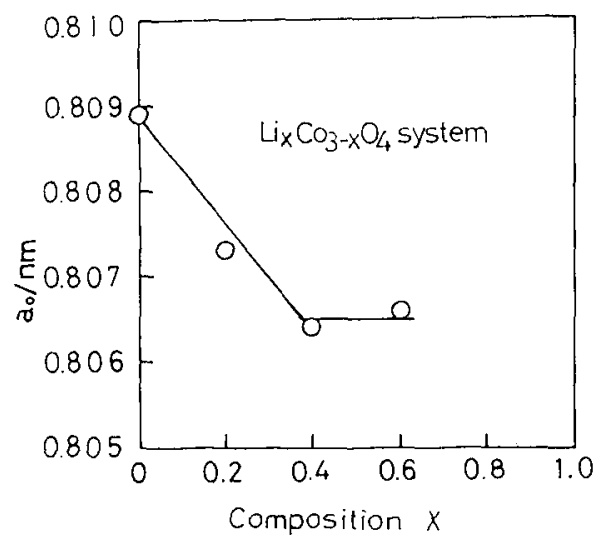

Fig. 2 Lattice constant vs. composition in the system of $\mathrm{Li}_{x} \mathrm{Co}_{3-x} \mathrm{O}_{4}$.

of both lithium and cobalt ions in the samples with $x=0.2,0.4$ were determined by means of an atomic absorption spectro-chemical analysis after washing the products with water. The both cation contents of products were in good agreement with those of the starting materials. The relation between the chemical composition and the lattice parameter is shown in Fig. 2. The lattice parameter decreased linearly with increasing $x$ from $x=0$ to 0.4 , but above $x=0.4$ it did not vary and products consisted of two phases as described before. From these results, it was concluded that the solid solutions of $\mathrm{Li}_{x} \mathrm{CO}_{3-x} \mathrm{O}_{4}$ with the cubic spinel type structure were synthesized from $x=0$ to 0.4 , under present high oxygen gas pressure conditions. The lattice parameter of $\mathrm{Co}_{3} \mathrm{O}_{4}$ synthesized in the present experiments was in good agreement with that reported by Lotgering.?

The temperature dependence of reciprocal magnetic susceptibility of the sample having the chemical composition of $\mathrm{Li}_{x} \mathrm{Co}_{3-x} \mathrm{O}_{4}(x=0,0.2,0.4)$ is shown in Fig. 3. All samples obeyed the Curie-Weiss law. The effective magnetic moment and the paramagnetic Curie temperature are shown in Fig. 4 as a function of the composition $x$. Blasse reported that $\mathrm{Co}_{3} \mathrm{O}_{4}$ was antiferromagnetic with a Néel temperature of $46 \mathrm{~K}$ and the effective magnetic moment was $4.20 \mu_{\mathrm{B}}{ }^{8)}$. The both values of effective magnetic moment and paramagnetic Curie temperature of $\mathrm{Co}_{3} \mathrm{O}_{4}$ synthesized under the present high oxygen' gas pressure experiments were in good agreement with those reported by Blasse ${ }^{8}$. The facts that effective magnetic moment and the absolute value of paramagnetic Curie temperature

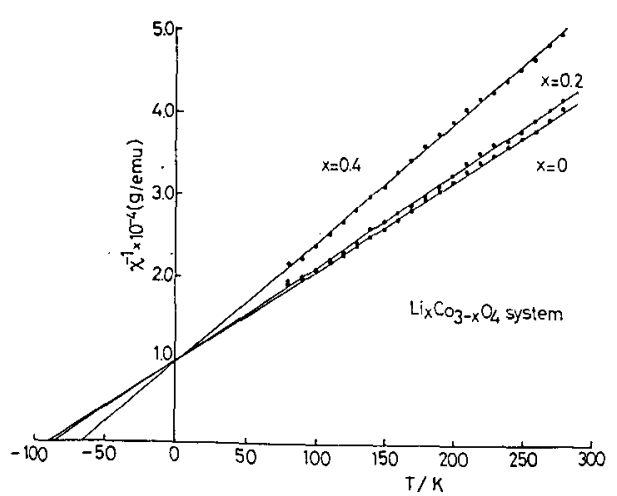

Fig. 3 Temperature dependence of the reciprocal magnetic susceptibility in the system of $\mathrm{Li}_{x} \mathrm{Co}_{3-x} \mathrm{O}_{4}$.

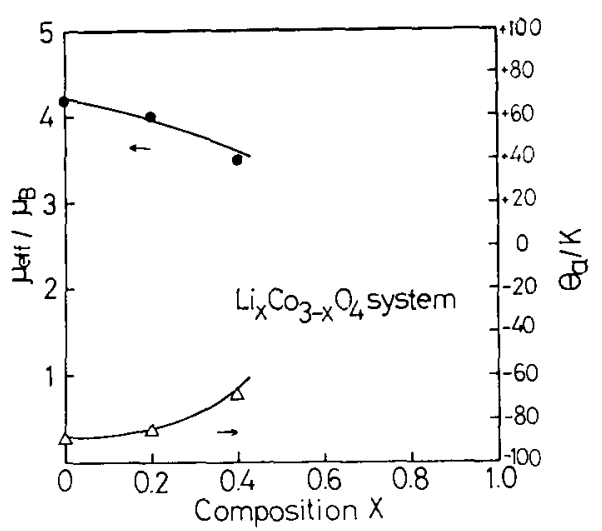

Fig. 4 Effective magnetic moment and paramagnetic Curie temperature in the system of $\mathrm{Li}_{x} \mathrm{Co}_{3-x}$ $\mathrm{O}_{4}$. 
Table 1 Possible cation distributions of $\mathrm{Li}_{x} \mathrm{Co}_{3-x} \mathrm{O}_{4}$

$$
\mathrm{Co}^{2+}\left[\mathrm{Co}_{2}^{\mathbb{1 1}+}\right] \mathrm{O}_{4}
$$

(a) $\mathrm{Li}_{x}^{+} \mathrm{Co}_{1-2 x}^{2+} \mathrm{Co}_{x}^{3+}\left[\mathrm{Co}_{2}^{11+}\right] \mathrm{O}_{4}$

(b) $\mathrm{Li}_{x}^{+} \mathrm{Co}_{1-x}^{2+}\left[\mathrm{Co}_{2-x}^{\mathrm{a}+} \mathrm{Co}_{x}^{4+}\right] \mathrm{O}_{4}$

(c) $\mathrm{Co}^{2}+\left[\mathrm{Li}_{x} \mathrm{Co}_{2-3 x}+\mathrm{Co}_{2 x}^{4+}\right] \mathrm{O}_{4}$

(d) $\mathrm{Co}_{1-2 x}^{2+} \mathrm{Co}_{2 x}^{3+}\left[\mathrm{Li}_{x}^{+} \mathrm{Co}_{2-x}^{\mathrm{I}+}\right] \mathrm{O}_{4}$

\begin{tabular}{cccc}
\hline Ion & Coordination number & Spin state & Ion radius/nm \\
\hline \multirow{2}{*}{$\mathrm{Li}^{+}$} & 4 & - & 0.059 \\
& 6 & - & 0.074 \\
\hline $\mathrm{Co}^{2+}$ & 4 & H.S* & $\sim 0.061$ \\
\hline \multirow{2}{*}{$\mathrm{Co}^{3+}$} & 4 & L.S** & $\sim 0.050$ \\
& & H.S & $\sim 0.062$ \\
& 6 & L.S & 0.0525 \\
\hline \multirow{2}{*}{$\mathrm{Co}^{4+}$} & 6 & L.S & 0.056 \\
& & H.S & 0.060 \\
\hline
\end{tabular}

* High Spin State

** Low Spin State

decreased with increasing $x$ suggested that the amount of the electron spin in this solid solution system decreased.

Considering the cation distribution and spin state of $\mathrm{Co}^{2+}$ and $\mathrm{Co}^{\mathbb{1}+}$ ions in the normal spinel structure of $\mathrm{Co}_{3} \mathrm{O}_{4}$ into account, the four kinds of possible cation distribution of the $\mathrm{Li}_{x} \mathrm{Co}_{3-x} \mathrm{O}_{4}$ $(0 \leqq x \leqq 0.4)$ shown in Table 1 were examined. As seen in Table 1 , in the case of (a) and (b), $\mathrm{Li}^{+}$ ions occupy the tetrahedral site and $\mathrm{Li}^{+}$ions occupy the octahedral site in case of (c) and (d). Considering that, in the system of $\mathrm{Li}_{x} \mathrm{Co}_{3-x} \mathrm{O}_{4}, \mathrm{Co}^{2+}$ ions located at tetrahedral site were high spin state and $\mathrm{Co}^{\square+}$ ions at octahedral site were low spin state as well as the spin state of Co ions in $\mathrm{CO}_{3} \mathrm{O}_{4}$ and cobaltite spinel oxides's), the compositional dependence of lattice parameter shown in Fig. 2 was examined as followings. By models (a), (b) and (d) listed in Table 1, the decrease of lattice parameter with increasing $x$ was well explained, but in the case of model (c) the lattice constant increased with increasing $x$.

It is possible to explain the result of compositional dependence of lattice constant in the system $\mathrm{Li}_{x} \mathrm{Co}_{3-x} \mathrm{O}_{4}$ under the assumption that $\mathrm{Co}^{\mathbb{}+}$ ions and $\mathrm{Co}^{4+}$ ions located at tetrahedral site were low spin state in the models (a), (b) and (d). In order to determine the most possible cation distributions of the present solid solution systems, the comparison of the compositional dependence of observed effective magnetic moments and that of calculated ones using proposed models of (a), (b) and (d) was examined. The result is shown in Fig. 5. As seen in Fig. 5, the compositional dependence of observed $\mu_{\text {eff }}$ agreed very closely with that calculated one using model (b). It is expected that the most possible cation distribution in the present system was $\mathrm{Li}_{x}^{1+} \mathrm{Co}_{1-x}^{2+}\left[\mathrm{Co}_{2-x}^{\mathbb{I +}} \mathrm{Co}_{x}^{4+}\right] \mathrm{O}_{4}(0 \leqq x \leqq 0.4)$.

The relation between the electrical resistivity and reciprocal temperature is shown in Fig. 6 . All samples were semiconductors. The electrical resistivity decreased steeply with increasing $x$, indicating that the mechanism of electron conductivity was owing to the hopping model.

III-2 $\mathrm{Li}_{x} \mathrm{Zn}_{1-x} \mathrm{Co}_{2} \mathrm{O}_{4}$ System

$\mathrm{X}$-ray powder diffraction patterns of the samples with the starting chemical compositions of $x=0$, $0.2,0.4$ synthesized under high temperature and high oxygen gas pressure condition were completely indexed as the cubic spinel type structure, but that of sample with $x=0.6$ consisted of two phases, main spinel phase and minor $\mathrm{LiCoO}_{2}$ phase. After washing the products with water, the lithium 


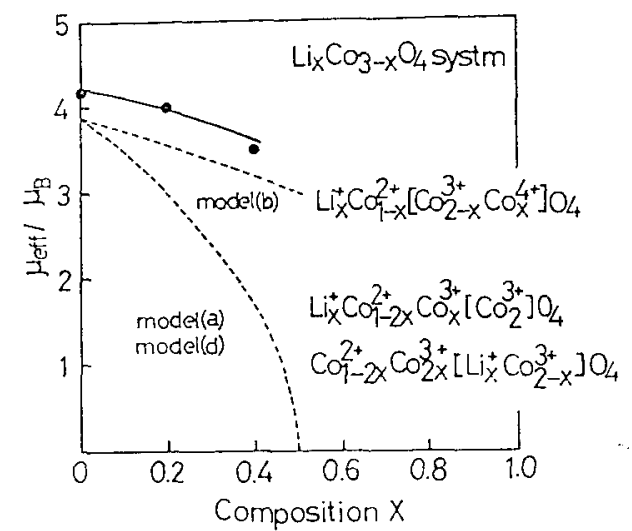

Fig. 5 Observed and calculated effective magnetic moments in the system of $\mathrm{Li}_{x} \mathrm{Co}_{3-x} \mathrm{O}_{4}$.

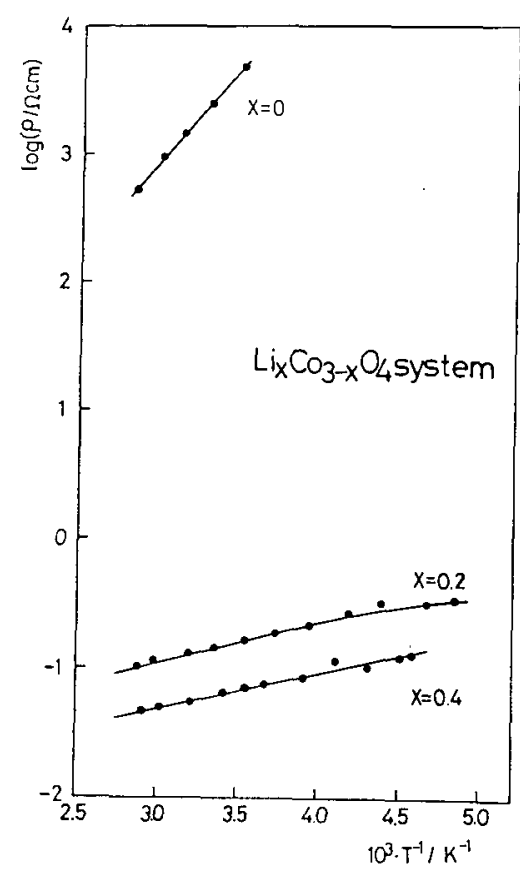

Fig. 6 Electrical resistivity vs. reciprocal temperature in the system of $\mathrm{Li}_{x} \mathrm{Co}_{3-x} \mathrm{O}_{4}$.

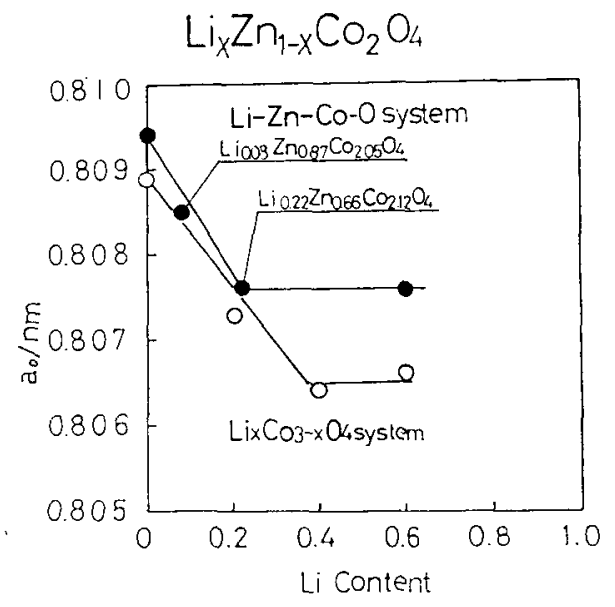

Fig. 7 Lattice constant vs. $\mathrm{Li}$ content in the systems of $\mathrm{Li}-\mathrm{Zn}-\mathrm{Co}-\mathrm{O}$ and $\mathrm{Li}_{x} \mathrm{Co}_{3-x} \mathrm{O}_{4}$.

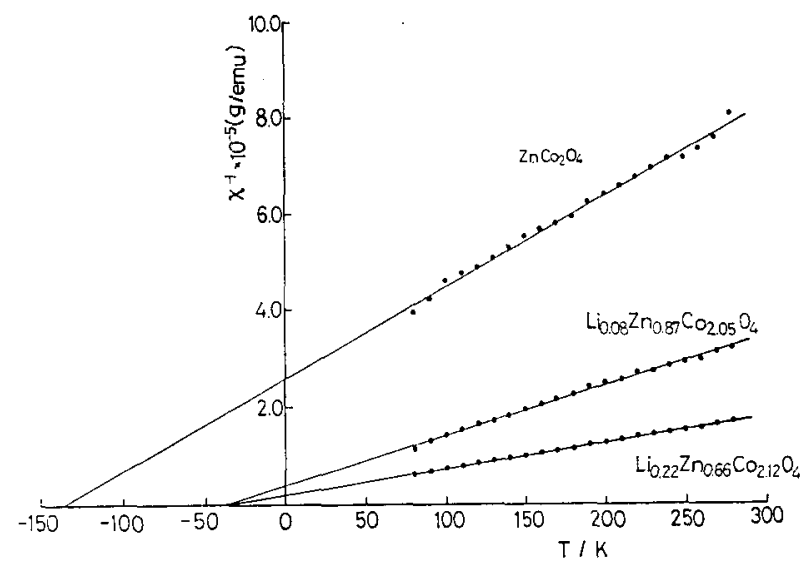

Fig. 8 Temperature dependence of the reciprocal magnetic susceptibility in the system of $\mathrm{Li}-\mathrm{Zn}-\mathrm{Co}-\mathrm{O}$.

contents in the samples with $x=0.2$ and 0.4 were determined by an atomic absorption spectro-chemical analysis. In the system of $\mathrm{Li}_{x} \mathrm{Zn}_{1-x} \mathrm{Co}_{2} \mathrm{O}_{4}$, lithium contents were about $50 \%$ of ideal formula. The relation between the lithium content and the lattice parameter is shown in Fig. 7. In this figure, the chemical formulae of $\mathrm{Li}_{x} \mathrm{Zn}_{1_{-x}} \mathrm{Co}_{2} \mathrm{O}_{4}$ determined by the spectro-chemical analysis and compositional dependence of lattice parameter of $\mathrm{Li}_{x} \mathrm{CO}_{3-x} \mathrm{O}_{4}$ are also shown. As seen in Fig. 7, the change of compositional dependence of lattice parameter of this system was almost similar to that of $\mathrm{Li}_{x} \mathrm{Co}_{3-x} \mathrm{O}_{4}$ system.

The temperature dependence of reciprocal magnetic susceptibility of the sample is shown in Fig. 8 . 


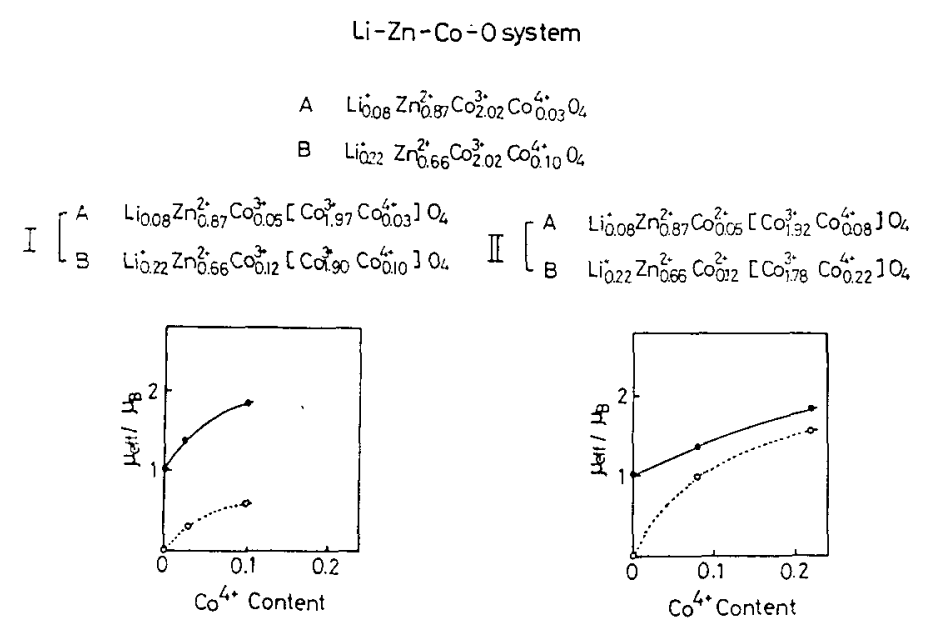

Fig. 9 Possible chemical formulae and observed and calculated effective magnetic moments in the system of $\mathrm{Li}-\mathrm{Zn}-\mathrm{Co}-\mathrm{O}$.

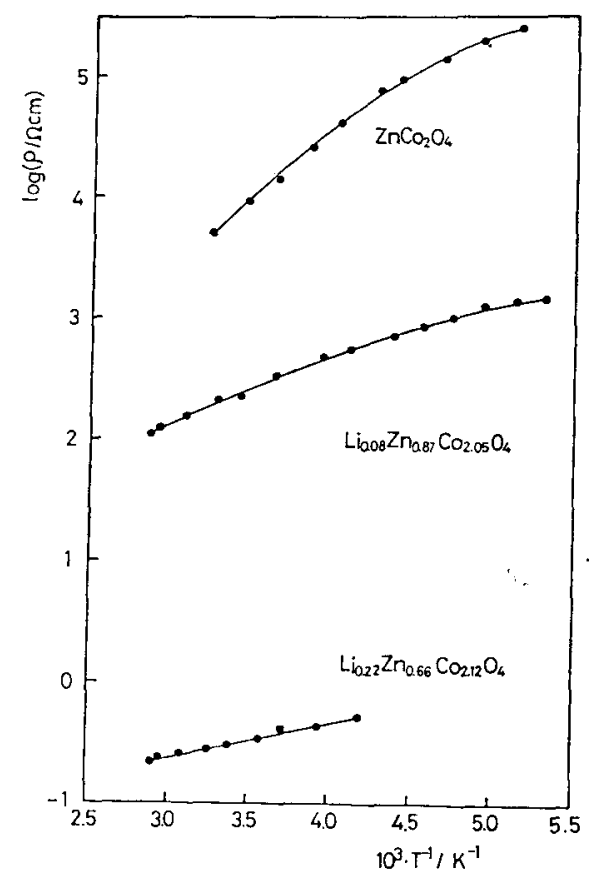

Fig. 10 Electrical resistivity vs. reciprocal temperature in the system of $\mathrm{Li}-\mathrm{Zn}-\mathrm{Co} \cdot \mathrm{O}$.

All samples obeyed the Curie-Weiss law in the temperature range of $80-280 \mathrm{~K}$ and their paramagnetic Curie temperature were negative. The chemical formulae of two samples of the present solid solutions might be represented as $\mathrm{A}$ and $\mathrm{B}$ shown in the upper part of Fig. 9. From the result that $\mathrm{Zn}^{2+}$ ions occupy the tetrahedral sites in $\mathrm{ZnCo}_{2} \mathrm{O}_{4}{ }^{7}$, it is considered that $\mathrm{Zn}^{2+}$ ions occupy the tetrahedral site in the present system. And, from the fact that the lattice constant of this system changed in the same manner as that of $\mathrm{Li}_{x} \mathrm{Co}_{3-x} \mathrm{O}_{4}$ as shown in Fig. 7, it is expected that $\mathrm{Li}^{+}$ions occupy the tetrahedral site in this system. The two possible cation distributions of samples may be represented by formulae I and II as shown in Fig. 9. In order to examine the most possible cation distributions of products, the effective magnetic moment of each model was calculated by assuming 
that $\mathrm{Co}^{2+}$ ions located at tetrahedral site were high spin state and both $\mathrm{Co}^{\mathbb{1}+}$ and $\mathrm{Co}^{4+}$ ions at octahedral site were low spin state. The calculated values are shown as the dotted line in Fig. 9. As seen in this figure, the observed values were in fairly agreement with the calculated ones using model II . The relation between the electrical resistivity and reciprocal temperature is shown in Fig. 10. The electrical resistivity decreased steeply with increasing $\mathrm{Co}^{4+}$ content in this system, indicating that the electron conductivity in the present system would be owing to the hopping mechanism.

\section{Reference}

1) A Deshanvres, B. Jaskowsky: Mater. Res. Bull, 6 (1971), 699.

2) B. Reuter and J. Jaskowsky: Angew. Chem., 72 (1960), 209.

3) D. G. Wickham and W. J. Croff: J. Phys. Chem. Solids, 7 (1958), 351.

4) F. Kanamaru, H. Miyamoto, Y. Mimura, M. Koizumi, M. Shimada and S. Shin: Mat. Res. Bull., 5 (1970), 257.

5) H. Taguchi, M. Shimada and M. Koizumi: J. Solid State Chem., 29 (1979), 221.

6) N. K. Appandairajan, B. Viswanathan and J. Gopalakrishnan: J. Solid State Chem., 40 (1981), 117.

7) F. K. Lotgering: Philips Res. Rept, 11 (1956), 190.

8) G. Blasse: Philips Res. Rept., 18 (1963), 383.

9) M. Shimada, N. Yamamoto and M. Koizumi, Mat. Res. Bull., 10 (1975), 733.

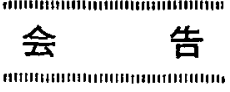

第21回 $\mathrm{X}$ 線 分析討 論会

共 催：日本分析化学会・同X線分析研究烈談会・日本 化学会・ESCA 研究会

協 賛 : 応用物理学協会ほか13学拹会

日 時：9月26日（水） 28日 (金)

会 場 : 関西大学会館（吹田市山手町3-3-35)

討論主題：1）ESCA 分析法一表面層の定量分析を中心 に一２）螢光X線分析装置の進歩と問題点，3）マ1 クロアナリシスと画像処理，4）その他

講演申込締切：5月12日（土）必着

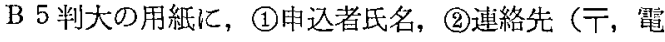
話番号，住所），(3)演題 (英文併記)，(4)発表者氏名

(講演者に○印，ローマ字併記），(5)所属（英文併記）, (6)討論主題(1)～(4)のいずれかを記入し、プログラム絀 成の都合上，100〜200字の講演概要を必ず記入してく ださい。講演特間は討論を含めて 1 件20分の予定です。 な打連絡先が自宅か勤務先か分加るようにしてくださ い。また，発表者氏名及び演題は特にはっきり御記入 ください。講演申込締切日を過ざて到着した場合は， 受理できない場合がありますので御注意ください。

講演要旨締切：6月23日（土）必着

講演申迈者に，所定の原稿用紙（脑・表・イラストを 含めて約2,500字）を打送りしますから，必ず期日ま でに提出してください，期日を過ぎますと㱠旨集に揭 載できないこともありますので御注意ください。
講演申込・要旨提出先：干141 東京都品川区酉五反田一 丁目26番 2 号 五反田サンハイツ304号 日本分析化学会X線分析研究㸸談会

（電話：03-490-3351代)

\section{第4回 国際造粒シンポジウム \\ (4th International Symposium on Agglomeration)}

日 時：1985年 6 月 2 日〜 5 日，カナダ・トロント． 申込み締切：1984年 5 月 1 日まで，400〜500語.

受理の連絡：7月1日

原稿締切：1984年11月 1 日.

日本国内の問い合わせ先：粉体工学念 干606 京都市左索区田中関田町2-7 舁文閣会館33号 TEL (075) 751-0195 $751-7123$

または淔接下記へ

Professor J. R. Wynnyckyj

Agglomeration'85

Department of Chemical Engineering

University of Waterloo

Waterloo, Ontario N2L 3GI Canada 